\title{
Statistical Analysis of Uranium-Mill \\ Raffinate Contamination in \\ Water Wells in Lincoln Park, \\ South-Central Colorado
}

by Edward R. Banta

U.S. GEOLOGICAL SURVEY

Water-Resources Investigations Report 93-4211

Prepared in cooperation with the

U.S. ENVIRONMENTAL PROTECTION AGENCY

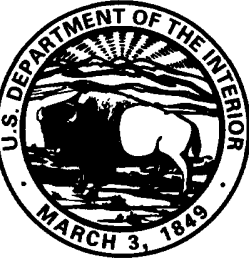




\section{U.S. DEPARTMENT OF THE INTERIOR}

\section{BRUCE BABBITT, Secretary}

U.S. GEOLOGICAL SURVEY

Robert M. Hirsch, Acting Director

The use of trade, product, industry, or firm names is for descriptive purposes only and does not imply endorsement by the U.S. Government.

For additional information write to:

Copies of this report can be purchased from:

District Chief

U.S. Geological Survey

Box 25046, MS 415

Denver Federal Center

Denver, CO 80225
U.S. Geological Survey

Earth Science Information Center

Open-File Reports Section

Box 25286, MS 517

Denver Federal Center

Denver, CO 80225 


\section{CONTENTS}

Abstract
Introduction
Purpose and scope
Site description and previous work
Statistical methods
Acknowledgments
Statistical analysis of raffinate contamination
Which wells are raffinate affected?

\section{FIGURES}

1. Map showing well locations and direction of ground-water flow in the alluvial aquifer at Lincoln Park

2. Chart showing sample dates for wells completed in the alluvial aquifer

\section{TABLES}

1. Example use of sign test to determine if a well is raffinate affected, for well 7 relative to background well 114 at Lincoln Park, Colorado.....

2. Summary of results of sign tests to determine which wells at Lincoln Park, Colorado, are raffinate affected

3. Ranked 1989 median uranium concentrations in water samples from raffinate-affected wells at Lincoln Park, Colorado.

Ranked 1989 median molybdenum concentrations in water samples from raffinate-affected wells at Lincoln Park, Colorado...

5. Results of sign test to determine if compliance wells 19 and 20 are representative of other raffinate-affected wells downgradient from the DeWeese Dye Ditch at Lincoln Park, Colorado......................... 10

6. Results of sign test to determine if compliance wells 19 and 20 are representative of other raffinate-affected wells upgradient from the DeWeese Dye Ditch at Lincoln Park, Colorado...............................

\section{CONVERSION FACTOR AND VERTICAL DATUM}

\begin{tabular}{lll}
\hline Multiply & By & To obtain \\
\hline foot (ft) & 0.3048 & meter \\
\hline
\end{tabular}

The following term and abbreviation also is used in this report:

milligram per liter (mg/L)

National Geodetic Vertical Datum of 1929: A geodetic datum derived from a general adjustment of the first-order level nets of both the United States and Canada, formerly called Sea Level Datum of 1929. 


\title{
Statistical Analysis of Uranium-Mill Raffinate Contamination in Water Wells in Lincoln Park, South-Central Colorado
}

\author{
By Edward R. Banta
}

\section{Abstract}

An alluvial aquifer in Lincoln Park, Colorado, is contaminated by raffinate from a nearby uranium mill. Analysis of ground-water-quality data for samples from wells completed in the alluvial aquifer indicates that 16 wells have concentrations of uranium or molybdenum or both (constituents that are indicative of raffinate contamination) that are statistically significantly larger than background concentrations. Leakage from an irrigation ditch, which seasonally transports water virtually free of these constituents, results in decreased concentrations of these constituents in ground water. Water samples from raffinate-affected wells downgradient from the ditch have significantly smaller concentrations of uranium and molybdenum than do samples from raffinate-affected wells upgradient from the ditch. Water samples from one of two compliance wells, which are specified in a remedial action plan and are located downgradient from the ditch, tend to have larger concentrations of molybdenum than do samples from raffinate-affected wells downgradient from the ditch, other than the compliance wells. Otherwise, samples from the two compliance wells can be considered to be representative of samples from raffinate-affected wells downgradient from the ditch. Water samples from the compliance wells tend to have significantly smaller concentrations of uranium and molybdenum than do samples from raffinate-affected wells upgradient from the ditch.

\section{INTRODUCTION}

Lincoln Park, where an active uranium-ore processing mill is located, is the site of an investigation being conducted according to provisions of the Comprehensive Environmental Response, Compensation, and Liability Act of 1980 . The site has been included in the National Priority List of hazardous-waste sites
(U.S. Environmental Protection Agency, 1984). Many water wells completed in the alluvial aquifer in Lincoln Park produce water that has concentrations of uranium and molybdenum greater than background concentrations. These metals, which ordinarily are present in ground water at trace levels, if at all, are characteristic of raffinate (liquid waste) from the uranium milling and refining process. As part of the planned remediation of the site, ground water has been sampled and analyzed on a quarterly or monthly basis at a number of domestic and irrigation wells in Lincoln Park. In addition, two monitoring wells, also completed in the alluvial material, were installed to serve as compliance wells.

Under a cooperative agreement between the U.S. Geological Survey and the U.S. Environmental Protection Agency, a study was done to determine if available data support the conclusion that water samples from the two compliance wells are representative, with respect to raffinate-derived constituents, of water from raffinate-affected wells in Lincoln Park. Statistical analysis of the data was begun in April 1992 and was concluded in December 1992.

\section{Purpose and Scope}

This report presents results of the investigation to determine whether available data support the conclusion that water samples from the two compliance wells are representative, with respect to raffinate-derived constituents, of water from raffinate-affected wells in Lincoln Park.

Data used in this investigation were of two principal types: ground-water-quality data and wellconstruction data. Water-quality data for samples from 397 wells and test holes were obtained from a Cotter Corporation computer data base on floppy disk. Information in the data base includes well-identification number, sample date, water-quality constituent, concentration of the water-quality constituent, and a sample code used to distinguish among two or more samples taken from the same well on the same day. Of the wells for which water-quality data were supplied, 
20 are completed in the alluvial aquifer in Lincoln Park (fig. 1). Data were supplied for 1,740 samples from these 20 wells; the sample dates range from November 10, 1961, to December 19, 1991 (fig. 2). The compliance wells are wells 19 and 20. Available information about well construction and lithology of materials penetrated during construction of the 20 wells also was provided by Cotter Corporation (written commun., 1991).

\section{Site Description and Previous Work}

The area of concern in this investigation is an area of Lincoln Park between the Arkansas River on the north and a topographic ridge, seen as a westnorthwest-trending series of topographic highs in figure 1, on the south. The uranium-processing area of the mill property is south of the ridge. Sand Creek drains the processing area, and its course crosses the ridge in the northeast quarter of sec. 9, T. 19 S., R. 70 W. Sand Creek currently (1992) is dammed by a U.S. Soil Conservation Service dam (hereinafter referred to as the SCS dam).

Scott (1977) mapped the geology of the area and provided a detailed description of the geologic units. Numerous unpublished reports describing the hydrology of the area have been submitted by the Cotter Corporation to the U.S. Environmental Protection Agency and the Colorado Department of Health throughout the investigation of ground-water contamination in the area. Hearne and Litke (1987) presented an analysis of the ground-water hydrology and groundwater quality of the mill site and downgradient areas in Lincoln Park.

The near-surface earth materials in the area of concern include alluvium of Quaternary age and terrace deposits and underlying beds of the Vermejo Formation, Trinidad Sandstone, and Pierre Shale of Cretaceous age (Scott, 1977). The Quaternary deposits generally are 20 to $60 \mathrm{ft}$ thick and comprise bouldery, cobbly gravel and clayey, pebbly sand and silt. Underlying the Quaternary deposits are one or more of the Cretaceous formations. The Vermejo Formation is sandstone interbedded with shale and coal beds and is the uppermost of the Cretaceous formations. Below the Vermejo Formation is the Trinidad Sandstone, which comprises friable sandstone interbedded with carbonaceous shale. The Pierre Shale, which underlies the Trinidad Sandstone, is a thick (about $3,900 \mathrm{ft}$ ) marine shale. Because of erosional truncation of the Cretaceous formations, the Quaternary deposits directly overlie the Pierre Shale (the oldest of the Cretaceous formations) in the northern part of the area; whereas, to the south, the Quaternary deposits overlie progressively younger units, the Trinidad Sandstone and Vermejo Formation. The uppermost beds of the Cretaceous formations commonly are weathered or fractured or both. See Scott (1977) for more detailed information about the geology of the area.

Saturated parts of the Quaternary deposits and adjacent weathered or fractured parts of the Pierre Shale, Trinidad Sandstone, and Vermejo Formation yield water to numerous domestic and irrigation wells in the Lincoln Park area. In this report, these units are referred to as the "alluvial aquifer" to follow usage of Hearne and Litke (1987). A major control on the presence, amount, and quality of water in the alluvial aquifer is the DeWeese Dye Ditch, which contributes water to the alluvial aquifer on a seasonal basis. The DeWeese Dye Ditch has water in it from about April through October each year, and it is dry the rest of the year. Seasonal fluctuations in water levels in wells completed in the alluvial aquifer in the vicinity of the ditch result from leakage of water from the ditch when it contains water. North of the DeWeese Dye Ditch, ground water in the alluvial aquifer generally flows northeastward toward the Arkansas River (fig. 1). South of the ditch, Quaternary deposits generally are unsaturated; however, leakage from the ditch during the irrigation season when the ditch has water in it seasonally results in water-table rises and more widespread saturation of the Quaternary deposits near the ditch.

The gap in the ridge at Sand Creek (the current site of the SCS dam) likely was the primary path by which raffinate-derived constituents entered the shallow ground-water system at Lincoln Park. Hearne and Litke (1987) concluded that alluvium along Sand Creek, and possibly alluvium-filled channels in the upper surface of the Vermejo Formation south of the ditch, likely provided a path for raffinate-derived contaminants to follow from the gap in the ridge to Lincoln Park. See Hearne and Litke (1987) for more information about the ground-water hydrology of the area.

\section{Statistical Methods}

Two nonparametric statistical tests were used in this study to evaluate a series of questions related to the principal purpose of the investigation, which is to determine whether or not water samples from the two compliance wells are representative of raffinateaffected wells in Lincoln Park, with respect to raffinatederived constituents. Nonparametric tests were used for two reasons: (1) Nonparametric tests do not require the assumption that the data are normally distributed, 


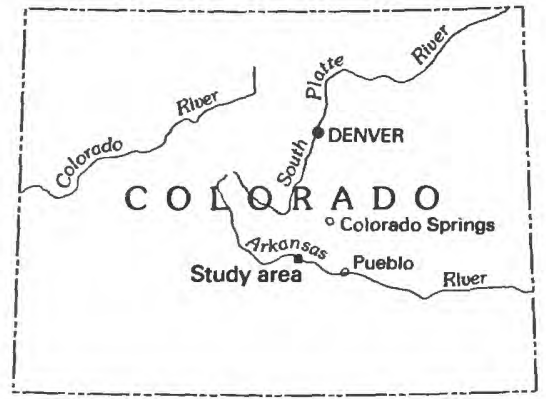

\section{EXPLANATION}

CONTACT - Approximate southern limit of Quaternary deposits and weathered and (or) fractured Cretaceous rocks that comprise the alluvial aquifer. Dashed where inferred

DIRECTION OF GROUND-WATER FLOW IN THE ALLUVIAL AQUIFER-Interpreted from Hearne and Litke (1987)

- 10 WELL AND NUMBER-Completed in the alluvial aquifer

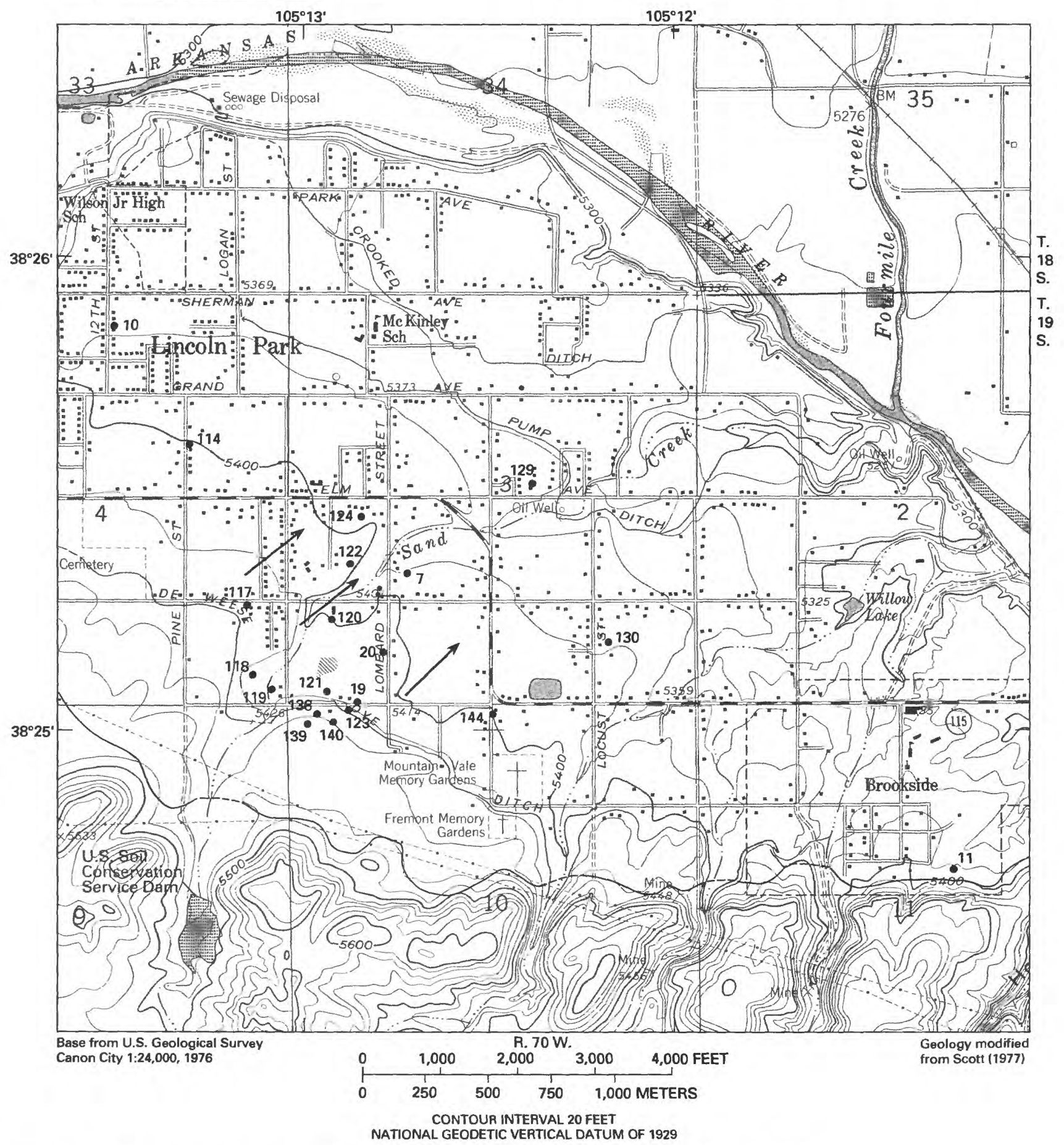

Figure 1. Well locations and direction of ground-water flow in the alluvial aquifer at Lincoln Park. 


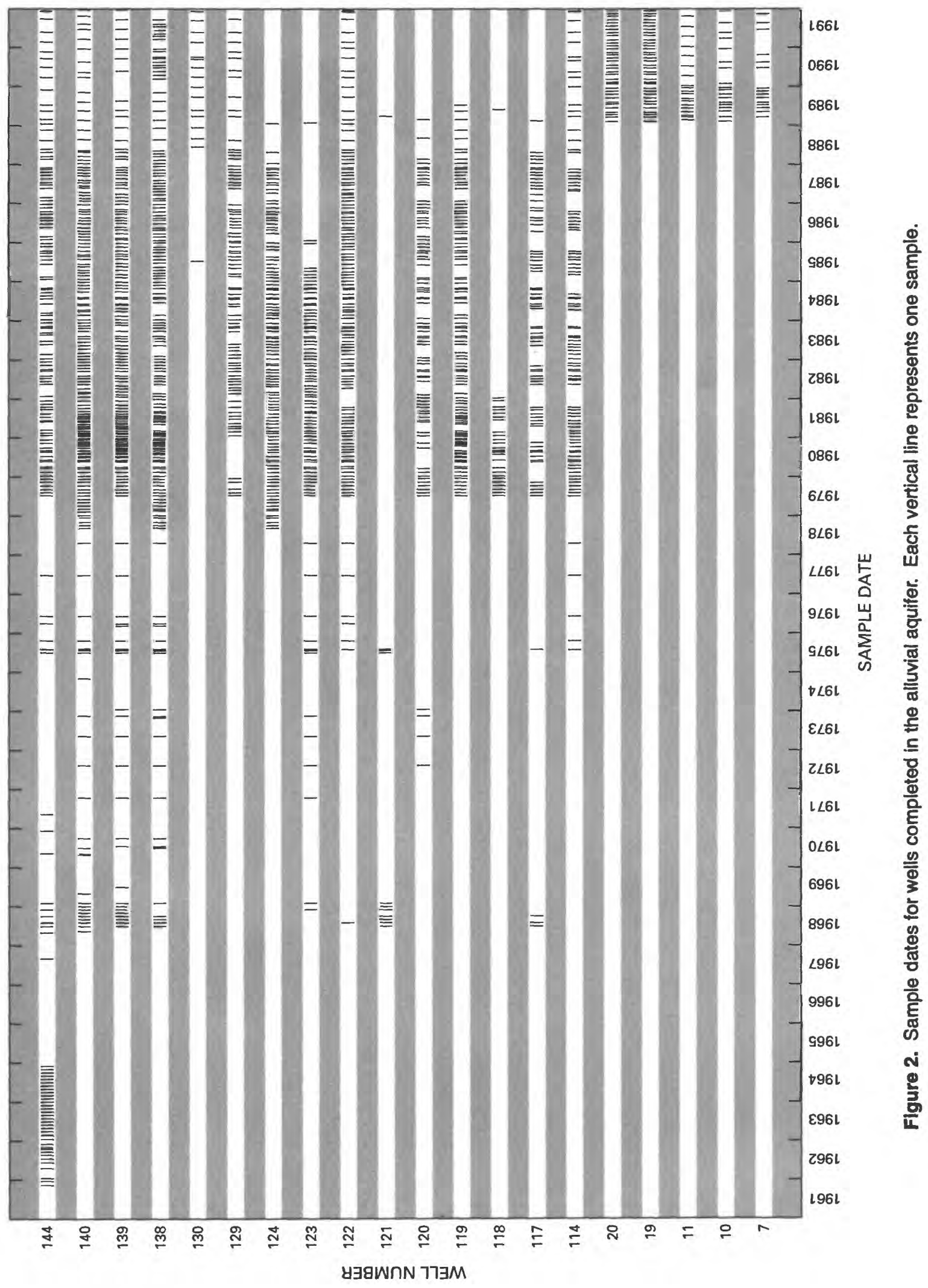


an assumption that may well be incorrect; and (2) for the tests selected, concentration values that are reported as less than some detection limit, a common occurrence in the data set used in this investigation, often can be used as is, without the need to assume some value for them. The first test is the sign test (Conover, 1980, p. 122-128), which was used to test paired data to determine if concentration values from one well were equal or not equal to concentration values from another well or from a group of wells. In using the sign test, the following assumptions are made: (1) The pairs of observations are mutually independent; and (2) the pairs of observations are internally consistent, in that if the probability of finding a larger constituent concentration in water from the first well than in water from the second well of a pair exceeds the probability of finding a smaller concentration in water from the first well for one pair of observations, then the same is true for all pairs of observations for the same two wells. The second test is the Mann-Whitney rank-sum test (Conover, 1980, p. 215-223), which was used to test data from wells in two areas of Lincoln Park to determine if the wells belong to a single population or to two separate populations. In using the Mann-Whitney test, the following assumptions are made: (1) Both samples are random samples from their respective populations, and (2) the samples are mutually independent. For each test, null and alternative hypotheses were formulated and tested.

One of two significance (alpha) levels was used in each test, depending on whether it was preferable to lessen the probability of making a type-I error (rejecting the null hypothesis when it is true) or to lessen the probability of making a type-II error (accepting the null hypothesis when it is false). An alpha level of 0.01 was selected where it was desirable to lessen the probability of making a type-I error, and an alpha level of 0.1 was selected where it was desirable to lessen the probability of making a type-II error.

\section{Acknowledgments}

The author thanks the mill owner, Cotter Corporation, for providing ground-water-quality and wellconstruction data, and for providing a guide for a site visit of the mill facility and surrounding area. The author also thanks Philip Stoffey of the Colorado Department of Health for his contribution to the success of the site visit.

\section{STATISTICAL ANALYSIS OF RAFFINATE CONTAMINATION}

To determine if samples from the compliance wells are representative of water from raffinateaffected wells in Lincoln Park, three questions needed to be addressed:

(1) Which wells in Lincoln Park are raffinate affected?

(2) Are the raffinate-affected wells identified in question (1) members of a single population or of two populations, separated by DeWeese Dye Ditch?

(3) Are the compliance wells representative of either a single population or one of two populations, depending on the outcome of question (2), of raffinateaffected wells in Lincoln Park?

Each of these questions is addressed by using one of the two statistical tests discussed in the previous section.

\section{Which Wells are Raffinate Affected?}

To answer question (1), a standard of comparison is needed in deciding which of the wells in Lincoln Park are raffinate affected. Because the point where raffinate-derived contaminants likely entered the aquifer is at the upgradient edge of the affected aquifer, it is impossible to install a monitoring well upgradient from the contaminant source in the same aquifer. The best alternative in this situation is to use a nearby well in the same aquifer that, because of its position relative to the contaminant source and the direction of ground-water flow, would be unaffected by a plume of contamination from the source and could be assumed to represent background conditions. To minimize the probability of errors in the statistical analyses, it is desirable that the well selected to represent background conditions have available a number of water-quality analyses similar to the number available for the wells in question, or more. Wells 10 and 114 meet the first criterion, as they are completed in the alluvial aquifer and are close to the contaminant source without being downgradient from the source themselves (fig. 1). As can be seen in figure 2 , however, available sample analyses for well 114 are more numerous and are representative of a longer period of time than are the sample analyses from well 10. In several instances, only one pair of observations for use in the sign test could be generated by using data from well 10 and a well of interest. For these reasons, well 114 was selected to represent background conditions. Where data were available to produce enough pairs of observations for well 10 and a well of interest that the statistical test used could produce significant 
results at the selected alpha level, the well of interest also was tested against well 10 to corroborate the conclusion as to whether or not the well is raffinate affected.

Each of the wells completed in the alluvial aquifer in Lincoln Park for which data were supplied was tested against well 114 by using the sign test. The null and alternative hypotheses can be stated as follows:

Null hypothesis: the probability of a " + " outcome is less than or equal to the probability of a "-" outcome, and

Alternative hypothesis: the probability of a " + " outcome is greater than the probability of a "-" outcome,

where a " + " outcome for a selected constituent indicates the concentration in a sample from the well in question exceeds the concentration in a corresponding sample from well 114, and a "-" indicates the concentration in a sample from the well in question is less than the concentration in a corresponding sample from well 114. The test statistic is the number of "+" outcomes. The test statistic is compared with a value from a table of the binomial distribution for the relevant number of cases and significance level to determine if the null hypothesis can be rejected. Ties are not taken into consideration. To frame the hypotheses in terms of constituent concentration, the null and alternative hypotheses also may, under certain assumptions, be stated in terms of expected values (Conover, 1980):

Null hypothesis: the expected value of the concentration of a constituent in a sample from a well of interest is less than or equal to the expected value of the concentration of the constituent in a sample from well 114.

Alternative hypothesis: the expected value of the concentration of a constituent in a sample from a well of interest is greater than the expected value of the concentration of the constituent in a sample from well 114.

To lessen the chance of concluding that a particular well is raffinate affected if it is not (a type-I error), the alpha level was chosen as 0.01 . The test is a onetailed test because the concentration of raffinatederived constituents would be greater in samples from raffinate-affected wells than in samples from nonraffinate-affected wells.

Data values were paired on the basis of the quarter of the year in which the samples were taken; where more than one pair of samples could be matched for a given quarter as a result of monthly sampling, data were paired on the basis of the month in which samples were taken. Where more than one sample for a given quarter from one well could be paired with only one sample for the quarter from another well, the samples that could be paired on the basis of the month or closest match in sampling dates were used. Where intervals between sampling dates were equal for two or more possible pairings, a situation that arises where more than one sample was obtained from a given well in a single day, a median concentration for the multiple sampled well was used.

As an example of the use of the sign test, the details of the test to determine if well 7 is raffinate affected relative to well 114 are listed in table 1. Pairing of observations by quarter for wells 7 and 114 produced 10 pairs. For uranium, two "+" outcomes and seven "-" outcomes were obtained, for a total of nine cases. For nine cases and alpha $=0.01$, a critical value of 9 is obtained from a table of the binomial distribution. The test statistic is 2 , the number of "+" outcomes, and 2 is not greater than or equal to 9 , so the null hypothesis is accepted for uranium. The probability of a type-I error for this test is $\mathbf{0 . 9 8 0 5}$. In the case of molybdenum, the concentration at well 7 exceeded that at well 114 in each pair. For 10 cases and alpha $=0.01$, the table value is 9 . Because 10 " + " outcomes were recorded, the test statistic is 10 . This value is greater than or equal to 9, the value from the table of the binomial distribution, so the null hypothesis can be rejected for molybdenum. The probability of a type-I error for this test is $\mathbf{0 . 0 0 1 0}$. For the purposes of this investigation, a well was considered raffinate affected if the null hypothesis could be rejected for either of the two constituents considered; therefore, well 7 was considered to be raffinate affected relative to well 114 . Hence, the actual probability of a type-I error equals $1-(0.99)^{2}$ or 0.0199 .

Summarized results for all wells tested are listed in table 2. The results of these tests indicate that wells $7,19,20,117,118,119,120,122,123,124,129,130$, $138,139,140$, and 144 are raffinate affected. The null hypothesis could not be rejected for wells 11 and 121; however, the number of data pairs for well 121 was insufficient to make a conclusion regarding rejection or acceptance of the null hypothesis at the selected alpha level.

\section{Is There More Than One Population of Raffinate-Affected Wells?}

Before the question of whether or not the compliance wells are representative of a group of raffinateaffected wells can be addressed, the distribution of constituent concentrations in the group needs to be consid- 
Table 1. Example use of sign test to determine if a well is raffinate affected, for well 7 relative to background well 114 at Lincoln Park, Colorado

[Concentrations in milligrams per liter; outcome is " + " if well 7 concentration exceeds well 114 concentration, " 0 " if concentrations are equal, and "-" if well 7 concentration is less than well 114 concentration]

\begin{tabular}{|c|c|c|c|c|c|c|}
\hline \multirow{3}{*}{ Year/quarter } & \multicolumn{3}{|c|}{ Uranium } & \multicolumn{3}{|c|}{ Molybdenum } \\
\hline & \multicolumn{2}{|c|}{ Concentration } & \multirow{2}{*}{ Outcome } & \multicolumn{2}{|c|}{ Concentration } & \multirow{2}{*}{ Outcome } \\
\hline & Well 7 & Well 114 & & Well 7 & Well 114 & \\
\hline $1989 / 1$ & 0.023 & 0.009 & + & 0.097 & 0.009 & + \\
\hline $1989 / 2$ & .014 & .012 & + & .047 & .005 & + \\
\hline $1989 / 3$ & .008 & .010 & - & .056 & .007 & + \\
\hline $1989 / 4$ & .008 & .010 & - & .109 & .007 & + \\
\hline $1990 / 2$ & .010 & .013 & - & .045 & .006 & + \\
\hline $1990 / 3$ & .009 & .011 & - & .043 & .011 & + \\
\hline $1990 / 4$ & .009 & .011 & - & .036 & .007 & + \\
\hline $1991 / 2$ & .013 & .015 & - & .040 & .006 & + \\
\hline $1991 / 3$ & .011 & .011 & 0 & .040 & .007 & + \\
\hline \multirow[t]{4}{*}{$1991 / 4$} & .007 & .011 & - & .034 & .009 & + \\
\hline & \multicolumn{2}{|c|}{ Number of " + " outcomes: } & 2 & & & 10 \\
\hline & \multicolumn{2}{|c|}{ Number of "-" outcomes: } & 7 & & & 0 \\
\hline & \multicolumn{2}{|c|}{ Sign-test population size: } & 9 & & & 10 \\
\hline
\end{tabular}

ered. Leakage from the DeWeese Dye Ditch, which seasonally transports water from the Arkansas River that is virtually free of uranium and molybdenum (Hearne and Litke, 1987), can be expected to decrease concentrations of these constituents in ground water by dilution. Because ground-water flow is from southwest to northeast, wells northeast of the ditch can be expected to have generally smaller concentrations of these constituents than wells southwest of the ditch. If wells on the downgradient side of the ditch can be determined to have significantly smaller concentrations of raffinate-derived constituents than wells on the upgradient side of the ditch, then two distinctly different populations of raffinate-affected wells are present in the group of wells under consideration. If there are two populations, the logical next step would be to compare data from the compliance wells to data from each of the two populations individually to determine if the compliance wells are representative of either of the two populations. The Mann-Whitney rank-sum test was used to determine if water samples from wells downgradient from the ditch have smaller concentrations of raffinate-derived constituents than samples from wells upgradient from the ditch.

Selection of data to be used in this test was based, in part, on data availability. As is shown in figure 2, water-quality monitoring began in 1989 at several of the wells for which data are available, including compliance wells 19 and 20. At several other wells, monitoring took place over a substantial period of time, then was discontinued after 1989. As a result, the monitoring periods coincide for all the wells under consideration only during 1989 . For this reason, only 1989 data are used in this test. To ensure that each well is represented with equal weight, one concentration value for each well is used in each analysis. The 1989 median concentration was determined to represent each well, and the analysis was done for each of the two constituents of interest, uranium and molybdenum.

In the Mann-Whitney test, observations from two groups are ranked as if in only one group, rank values are assigned, and the sum of the ranks of one of the groups is compared to a tabled value that is based on sample size of the two groups and the selected alpha level to determine if one of the groups tends to have larger or smaller values than the other group. To lessen the chance of concluding that the raffinate-affected wells belong to a single population if they do not (a type-II error), the alpha level was chosen as 0.1 . The test is a one-tailed test because the concentrations of raffinate-derived constituents can be expected to be less in samples from wells downgradient from the ditch than in wells upgradient from the ditch. The null and alternative hypotheses can be stated as follows: 
Table 2. Summary of results of sign tests to determine which wells at Lincoln Park, Colorado, are raffinate affected

$[<$, less than. The null hypothesis can be rejected at alpha $=0.01$ for tests for which the listed probability of a type-I error is less than 0.01 . For alpha $=0.01$ and sample sizes less than six, the null hypothesis cannot be rejected using the sign test. Table entry "Sample size too small" indicates that the number of pairs of observations is less than six]

\begin{tabular}{|c|c|c|c|c|}
\hline \multirow{3}{*}{ Tested well } & \multicolumn{4}{|c|}{ Probability of type-l error } \\
\hline & \multicolumn{2}{|c|}{ Comparison to well 114} & \multicolumn{2}{|c|}{ Comparison to well 10} \\
\hline & Uranlum & Molybdenum & Uranium & Molybdenum \\
\hline 7 & 0.9805 & $0.0010^{*}$ & 0.9539 & $<0.0001^{*}$ \\
\hline 11 & .0730 & .1133 & .9616 & .0245 \\
\hline 19 & $.0002 *$ & $.0002 *$ & $.0007^{*}$ & $<.0001^{*}$ \\
\hline 20 & $.0002^{*}$ & $.0002 *$ & $<.0001^{*}$ & $<.0001^{*}$ \\
\hline 117 & $<.0001^{*}$ & $<.0001^{*}$ & \multicolumn{2}{|c|}{ Sample size too small. } \\
\hline 118 & $.0022 *$ & $<.0001^{*}$ & \multicolumn{2}{|c|}{ Sample size too small. } \\
\hline 119 & $<.0001^{*}$ & $<.0001^{*}$ & \multicolumn{2}{|c|}{ Sample size too small. } \\
\hline 120 & .2088 & $<.0001^{*}$ & \multicolumn{2}{|c|}{ Sample size too small. } \\
\hline 121 & \multicolumn{2}{|c|}{ Sample size too small. } & \multicolumn{2}{|c|}{ Sample size too small. } \\
\hline 122 & $<.0001^{*}$ & $<.0001^{*}$ & $.0032 *$ & $.0002 *$ \\
\hline 123 & $<.0001^{*}$ & $<.0001^{*}$ & \multicolumn{2}{|c|}{ Sample size too small. } \\
\hline 124 & $<.0001 *$ & $<.0001 *$ & \multicolumn{2}{|c|}{ Sample size too small. } \\
\hline 129 & $<.0001^{*}$ & $<.0001^{*}$ & $.0010^{*}$ & $.0010^{*}$ \\
\hline 130 & $.0003^{*}$ & $<.0001^{*}$ & .2539 & $.0002 *$ \\
\hline 138 & $<.0001^{*}$ & $<.0001^{*}$ & $.0002 *$ & $.0005^{*}$ \\
\hline 139 & $<.0001^{*}$ & $<.0001^{*}$ & $.0010^{*}$ & $.0020^{*}$ \\
\hline 140 & $<.0001^{*}$ & $<.0001^{*}$ & $.0002 *$ & $.0010 *$ \\
\hline 144 & $<.0001^{*}$ & $<.0001^{*}$ & $.0002^{*}$ & $.0002^{*}$ \\
\hline
\end{tabular}

Null hypothesis: the probability that the concentration in a sample taken from a well downgradient from the ditch is less than the concentration in a sample taken from a well upgradient from the ditch is less than or equal to one-half.

Alternative hypothesis: the probability that the concentration in a sample taken from a well downgradient from the ditch is less than the concentration in a sample taken from a well upgradient from the ditch is greater than one-half.

If the null hypothesis can be rejected at the selected alpha level, then one may conclude that the two groups represent two populations that differ in concentration of the constituent for which the test was done. For uranium, the sum of the ranks for the 13 wells downgradient from the ditch is 92 , and the sum of the ranks for the 3 wells upgradient from the ditch is 44 (table 3 ). For this analysis, the test statistic is the sum of ranks for the downgradient wells, 92. From a table of quantiles of the Mann-Whitney test statistic, for group samples of 3 and 13 and an alpha level of 0.1 , a value of 101 is obtained. Because the test statistic, 92 , is less than the table value, 101 , the null hypothesis can be rejected for uranium. The probability of a type-I error for this test is $\mathbf{0 . 0 0 3}$. The rankings of data for molybdenum (table 4) are similar to those for uranium, and the null hypothesis also can be rejected for molybdenum. The probability of a type-I error for this test is 0.001 . As a result of these two tests, one can conclude that the two groups of wells, separated by the DeWeese Dye Ditch, represent two distinct populations, for which uranium and molybdenum concentrations differ. 
Table 3. Ranked 1989 median uranium concentrations in water samples from raffinate-affected wells at Lincoln Park, Colorado

[mg/L, milligrams per liter]

\begin{tabular}{|c|c|c|c|}
\hline $\begin{array}{c}\text { Well } \\
\text { number }\end{array}$ & $\begin{array}{l}\text { Location relative } \\
\text { to DeWeese } \\
\text { Dye Ditch }\end{array}$ & $\begin{array}{c}\text { Uranium } \\
\text { concentration, } \\
1989 \text { median } \\
(\mathrm{mg} / \mathrm{l})\end{array}$ & Rank \\
\hline 138 & Upgradient & 0.320 & 16 \\
\hline 139 & Upgradient & .221 & 15 \\
\hline 119 & Downgradient & .127 & 14 \\
\hline 140 & Upgradient & .110 & 13 \\
\hline 124 & Downgradient & .080 & 12 \\
\hline 117 & Downgradient & .073 & 11 \\
\hline 122 & Downgradient & .071 & 10 \\
\hline 129 & Downgradient & .055 & 9 \\
\hline 123 & Downgradient & .054 & 8 \\
\hline 118 & Downgradient & .036 & 7 \\
\hline 20 & Downgradient & .034 & 6 \\
\hline 144 & Downgradient & .031 & 5 \\
\hline 19 & Downgradient & .027 & 4 \\
\hline 130 & Downgradient & .018 & 3 \\
\hline 120 & Downgradient & .015 & 2 \\
\hline 7 & Downgradient & .010 & 1 \\
\hline & \multicolumn{2}{|c|}{ Rank sum for 13 downgradient wells: } & 92 \\
\hline & \multicolumn{2}{|c|}{ Rank sum for 3 upgradient wells: } & 44 \\
\hline & \multicolumn{2}{|c|}{ Probability of a type-I error: } & 0.003 \\
\hline
\end{tabular}

\section{Are the Compliance Wells Representative of Raffinate-Affected Wells?}

This question is of central concern in this investigation, and it was addressed by using the sign test. In this test, each data pair included a concentration value that represents one of the compliance wells and a value that represents one of the two populations of raffinateaffected wells other than compliance wells. Quarterly median concentrations of the two constituents of interest were determined for each quarter of 1989 through 1991, the period of record for the compliance wells, for compliance well 19 , for compliance well 20 , for noncompliance wells downgradient from the ditch, and for wells upgradient from the ditch. Note that both of the compliance wells are downgradient from the ditch.

The sign test was done, as described in an earlier sec-
Table 4. Ranked 1989 median molybdenum concentrations in water samples from raffinate-affected wells at Lincoln Park, Colorado

[mg/L, milligrams per liter]

\begin{tabular}{rccc}
\hline $\begin{array}{c}\text { Well } \\
\text { number }\end{array}$ & $\begin{array}{c}\text { Location relative } \\
\text { to DeWoese } \\
\text { Dye Ditch }\end{array}$ & $\begin{array}{c}\text { Molybdenum } \\
\text { concentration, } \\
\text { 1989 median } \\
\text { (mg/) }\end{array}$ & Rank \\
\hline 138 & Upgradient & 6.900 & 16 \\
139 & Upgradient & 3.200 & 15 \\
140 & Upgradient & 1.700 & 14 \\
119 & Downgradient & .850 & 13 \\
123 & Downgradient & .390 & 12 \\
& & & \\
124 & Downgradient & .320 & 11 \\
118 & Downgradient & .300 & 9.5 \\
122 & Downgradient & .300 & 9.5 \\
19 & Downgradient & .205 & 8 \\
117 & Downgradient & .200 & 6.5 \\
& & & \\
129 & Downgradient & .200 & 6.5 \\
144 & Downgradient & .140 & 4.5 \\
120 & Downgradient & .140 & 4.5 \\
20 & Downgradient & .090 & 3 \\
7 & Downgradient & .046 & 2 \\
130 & Downgradient & .035 & 1 \\
\cline { 3 - 3 } & Rank sum for 13 downgradient wells: & 91 \\
& Rank sum for 3 upgradient wells: & 45 \\
& Probability of a type-I error: & 0.001 \\
\hline
\end{tabular}

tion, using these quarterly medians. To lessen the chance of concluding that the compliance wells are representative of raffinate-affected wells in Lincoln Park if they are not, the alpha level was chosen as 0.1 . The test is a two-tailed test because the assumption to be tested is that concentrations of uranium and molybdenum in samples from the compliance wells do not differ from those in samples from the noncompliance wells. The null and alternative hypotheses can be stated as follows:

Null hypothesis: the probability of a " + " outcome is equal to the probability of a "-" outcome, and

Alternative hypothesis: the probability of a " + " outcome is not equal to the probability of a "-" outcome,

where a " + " outcome indicates the quarterly median concentration of uranium (molybdenum) in samples from raffinate-affected noncompliance wells downgra- 
dient (upgradient) from the DeWeese Dye Ditch for a given quarter, exceeds the quarterly median concentration in corresponding samples from compliance well 19 (20), and a "-" indicates the quarterly median concentration in samples from noncompliance wells is less than the quarterly median concentration in samples from the compliance well. The alternative wordings enclosed in parentheses are shown to signify the eight tests required because of the eight possible combinations of the two compliance wells and two groups of raffinate-affected wells to which the compliance wells are to be compared for the two constituents of interest. The sample size for each of the 8 tests was 12.

Results of all tests to determine if the compliance wells are representative of raffinate-affected wells downgradient from DeWeese Dye Ditch are listed in table 5. The null hypothesis can be rejected for the test to determine if well 19 is representative of the downgradient noncompliance wells with respect to molybdenum. This test indicates that molybdenum concentraions in water samples from well 19 tend to be unequal to concentrations in water samples from noncompliance wells downgradient from the ditch. The null hypothesis could not be rejected for the other tests involving the compliance wells and the noncompliance wells downgradient from the ditch. On the basis of the results of the tests, one can conclude that water samples from well 19 are representative of raffinate-affected wells downgradient from the ditch with respect to uranium concentrations, and that samples from well 20 are representative of raffinate-affected wells downgradient from the ditch with respect to uranium and molybdenum concentrations.

Although samples from wells downgradient from the ditch have been determined, as a group, to have uranium and molybdenum concentrations smaller than samples from wells upgradient from the ditch, the sign test also was used to determine if each of the two compliance wells, by itself, was representative of the upgradient wells. Results of tests to determine if the compliance wells are representative of raffinateaffected wells upgradient from DeWeese Dye Ditch are listed in table 6. As in the tests involving the downgra-

Table 5. Results of sign test to determine if compliance wells 19 and 20 are representative of other raffinate-affected wells downgradient from the DeWeese Dye Ditch at Lincoln Park, Colorado

$[-$, not applicable $]$

\begin{tabular}{clcc}
\hline Compllance weli & Constituent & Probability of a type-i error & $\begin{array}{c}\text { If null hypothesis ls rejected, relation of } \\
\text { concentration at compliance weil to } \\
\text { concentration at other downgradient wells }\end{array}$ \\
\hline 19 & Uranium & 0.1460 & -- \\
19 & Molybdenum & $.0005^{*}$ & Greater than \\
20 & Uranium & .7744 & - \\
20 & Molybdenum & 1.0000 & - \\
\hline
\end{tabular}

*Reject null hypothesis.

Table 6. Results of sign test to determine if compliance wells 19 and 20 are representative of other raffinate-affected wells upgradient from the DeWeese Dye Ditch at Lincoln Park, Colorado

\begin{tabular}{clcc}
\hline Compllance well & Constituent & Probability of a type-l error & $\begin{array}{c}\text { If null hypothesis is rejected, relation of } \\
\text { concentration at compliance well to } \\
\text { concentration at upgradlent wells }\end{array}$ \\
\hline 19 & Uranium & $0.0005^{*}$ & Less than \\
19 & Molybdenum & $.0005^{*}$ & Less than \\
20 & Uranium & $.0005^{*}$ & Less than \\
20 & Molybdenum & $.0005^{*}$ & Less than \\
\hline
\end{tabular}


dient wells, 12 pairs of quarterly medians were evaluated for each test. In all four tests, the null hypothesis can be rejected, and one can conclude that concentrations of uranium and molybdenum in water samples from either of the compliance wells tend to be less than those in samples from raffinate-affected wells upgradient from the ditch.

\section{SUMMARY}

Analysis of ground-water-quality data for samples from wells completed in the alluvial aquifer at Lincoln Park in south-central Colorado indicates that concentrations of uranium or molybdenum or both (constituents that are characteristic of contamination by raffinate from the uranium-ore milling process) in 16 wells are statistically significantly larger than background concentrations. Of these 16 wells, 3 are upgradient from the DeWeese Dye Ditch, which seasonally transports water that is virtually free of these constituents. When water is in the ditch, some of it leaks into the aquifer and results in a decrease in concentration of these constituents in the ground water. Water samples from raffinate-affected wells downgradient from the ditch have been determined to have statistically significantly smaller concentrations of uranium and molybdenum than samples from raffinate-affected wells upgradient from the ditch. Because of this dilution, the raffinate-affected wells can be considered to comprise two populations, separated by the DeWeese Dye Ditch, that differ in their concentrations of uranium and molybdenum. Water samples from one of two compliance wells tend to have larger concentrations of molyb- denum than do samples from raffinate-affected wells downgradient from the ditch, other than the compliance wells. Otherwise, samples from the compliance wells can be considered to be representative of samples from raffinate-affected wells downgradient from the ditch. Water samples from the compliance wells tend to have significantly smaller concentrations of uranium and molybdenum than do samples from raffinate-affected wells upgradient from the ditch. As a result, samples from the compliance wells cannot be considered representative of samples from raffinate-affected wells upgradient from the ditch.

\section{REFERENCES CITED}

Conover, W.J., 1980, Practical nonparametric statistics (2d ed.): New York, Wiley, 493 p.

Hearne, G.A., and Litke, D.W., 1987, Ground-water flow and quality near Canon City, Colorado: U.S. Geological Survey Water-Resources Investigations Report 87-4014, 72 p.

Scott, G.R., 1977, Reconnaissance geologic map of the Canon City quadrangle, Fremont County, Colorado: U.S. Geological Survey Miscellaneous Field Studies Map MF-892, scale 1:24,000.

U.S. Environmental Protection Agency, 1984, Amendment to national oil and hazardous substance contingency plan; national priorities list, final rule: Federal Register, v. 49 , no. 185 , September 21,1984 , p. $37070-37090$. 